\title{
Pedagogical models for tambaqui creation (Colossoma macropomum) in diverse
}

\section{environments}

\author{
Maquetes pedagógicas para criação de tambaqui (Colossoma macropomum) em diversos ambientes \\ Modelos pedagógicos para la cría de tambaqui (Colossoma macropomum) en varios entornos
}

Received: 11/12/2020 | Reviewed: 11/13/2021 | Accept: 11/14/2021 | Published: 01/01/2021

Fabricio Nilo Lima da Silva

ORCID: https://orcid.org/0000-0002-6402-0540 Instituto Federal de Educação, Ciência e Tecnologia do Pará, Brazil E-mail: fabricio.nilo@ifpa.edu.br

Raoani Cruz Mendonça

ORCID: https://orcid.org/0000-0001-6629-680X Instituto Federal de Educação, Ciência e Tecnologia do Pará, Brazil

E-mail: raoani.mendonca@ifpa.edu.br

Manoel Luciano Aviz de Quadros

ORCID: https://orcid.org/0000-0002-8258-7620 Instituto Federal de Educação, Ciência e Tecnologia do Pará, Brazil E-mail: manoel.quadros@ifpa.edu.br

Aracy Sá Pereira

ORCID: https://orcid.org/0000-0003-1609-4024 Instituto Federal de Educação, Ciência e Tecnologia do Pará, Brazil E-mail: aracysapereira95@gmail.com

Antony Correa Paes

ORCID: https://orcid.org/0000-0003-2288-7776 Instituto Federal de Educação, Ciência e Tecnologia do Pará, Brazil E-mail: antonycorrea7@ outlook.com

Luã Caldas de Oliveira

ORCID: https://orcid.org/0000-0001-7246-8559 Instituto Federal de Educação, Ciência e Tecnologia do Pará, Brazil

E-mail: lua.oliveira@ifpa.edu.br

Ana Célia Barbosa Guedes

ORCID: https://orcid.org/0000-0003-4212-2252 Instituto Federal de Educação, Ciência e Tecnologia do Pará, Brazil E-mail: anacelia.guedes@ifpa.edu.br

Julia Siqueira Moreau

ORCID: https://orcid.org/0000-0002-0107-9262 Instituto Federal de Educação, Ciência e Tecnologia do Pará, Brazil E-mail: julia.moreau@ifpa.edu.br

Osnan Lennon Lameira Silva

ORCID: https://orcid.org/0000-0001-6516-5007

Universidade Federal do Pará, Brazil

E-mail: osnanlennon@hotmail.com

Elaine Vasconcelos Bezerra Alves

ORCID: https://orcid.org/0000-0001-6462-2026

Instituto Federal de Educação, Ciência e Tecnologia do Pará, Brazil

E-mail: elaine.bezerra@ifpa.edu.br

\begin{abstract}
The project "Technology transfer through training and technical assistance for tambaqui breeders (Colossoma macropomum) in the Marajó/PA archipelago is characterized by the opportunity for training, dissemination of technologies, quality academic professional training to students and others involved. For this, the municipality of Curralinho was the stage of extensionist actions realized by Instituto Federal de Educação, Ciência e Tecnologia do Pará (IFPA), Campus Breves. Active methodologies were used through the participation of teachers, fish farmers and students in the construction of pedagogical models. Thus, the objective of this work was to evaluate the use of different models for tambaqui creation. Three models were produced with perspective of implantation in different environments for the region of Marajó: floodplain area, dry land area and field area. A total of 13 fish farmers participated in this action, with whom the power of fixation attention, the understanding, the reflection and the sufficiency of time for each type of model built was evaluated. The Likert scale was used to analyze the data. The results showed that fish farming in floodplain areas presented the highest rates in the parameters studied, while the dry land area and field area models were less interesting in the opinions of the participants. In conclusion,
\end{abstract}


the use of active methodologies through models improved the learning process of the fish farmers during the educational actions of the extension project in aquaculture.

Keywords: Aquaculture; Active methodologies; Extension; Amazônia paraense.

\section{Resumo}

O projeto "Transferência de tecnologia através da capacitação e assistência técnica para criadores de tambaqui (Colossoma macropomum) no arquipélago do Marajó/PA, caracteriza-se pela oportunidade de capacitação, difusão de tecnologias, formação acadêmico-profissional de qualidade aos estudantes e demais envolvidos. Para isso, o município de Curralinho foi palco das ações extensionistas realizadas pelo Instituto Federal de Educação, Ciência e Tecnologia do Pará (IFPA), Campus Breves. Foram utilizadas metodologias ativas, por meio da participação de professores, aquicultores e estudantes, na construção de maquetes pedagógicas. Assim, o objetivo desse trabalho foi avaliar o uso de diferentes maquetes para criação de tambaqui. Foram produzidas três maquetes com perspectiva de implantação em diferentes ambientes para a região do Marajó: área de várzea, área de terra firme e área de campo. Um total de 13 aquicultores participaram dessa ação, com os quais se avaliou o poder de fixação da atenção, a compreensão, a reflexão e a suficiência do tempo para cada tipo de maquete construída. Para a análise dos dados, foi utilizada a escala de Likert. Os resultados mostraram que a piscicultura em área de várzea apresentou os maiores índices nos parâmetros estudados, enquanto as maquetes terra firme e campo foram menos interessantes nas opiniões dos participantes. Em conclusão, o uso de metodologias ativas por meio de maquetes melhorou o processo de aprendizagem dos piscicultores durante as ações educativas do projeto de extensão em aquicultura.

Palavras-chave: Aquicultura; Metodologias ativas; Extensão; Amazônia paraense.

\section{Resumen}

El proyecto "Transferencia de tecnología a través de capacitación y asistencia técnica para criadores de tambaqui (Colossoma macropomum) en el archipiélago de Marajó/PA, se caracteriza por la oportunidad de formación, difusión de tecnologías, formación académica y profesional de calidad para estudiantes y otros involucrados. Para eso, el municipio de Curralinho fue escenario de acciones de extensión que realiza el Instituto Federal de Educación, Ciencia y Tecnología de Pará (IFPA), Campus Breves. Se utilizaron metodologías activas, a través de la participación de docentes, acuicultores y estudiantes, en la construcción de modelos educativos. Así, el objetivo de este trabajo fue evaluar el uso de diferentes modelos para la creación de tambaqui. Se produjeron tres modelos con miras a la implantación en diferentes ambientes para la región de Marajó: zona de tierras bajas, zona de tierra firme y zona de campo. En esta acción participaron un total de 13 piscicultores, con lo cual se evaluó el poder de fijar la atención, comprensión, reflexión y suficiencia de tiempo para cada tipo de modelo construido. Para el análisis de los datos se utilizó la escala Likert. Los resultados mostraron que la piscicultura en una zona de tierras bajas tuvo los índices más altos en los parámetros estudiados, mientras que los modelos de tierra firme y de campo fueron menos interesantes en las opiniones de los participantes. En conclusión, el uso de metodologías activas a través de modelos mejoró el proceso de aprendizaje de los piscicultores durante las actividades educativas del proyecto de extensión acuícola.

Palabras clave: Acuicultura; Metodologías activas; Extensión; Amazônia paraense.

\section{Introduction}

The fishes, shrimps, oysters, turtles, alligators, aquatic plants, among others, are created/cultivated through aquaculture (Sousa et al., 2019). In Brazil, the fish farming corresponds to most of everything produced by aquaculture. The tambaqui (Colossoma macropomum) is one of the fish species, with high production potential and represents an important activity from the social and economic point of view. Mainly, in regions with low Human Development Indexes (HDI), such as the Marajó archipelago, located in the state of Pará, Brazil.

The Marajó presentss diverse natural ecosystems that can be divided into areas of floodplain, igapós, dry land and natural fields. These environments are potential for fish production in the region. In this context, fish farming can promote the supply of fish to the local population, in addition to generating income and fixing the man in the field (Cantisani et al., 2015). Thus, to overcome the obstacles to the development of this activity, the extension projects in aquaculture presents positive results (Alcântara et al., 2017; Ituassú \& Aragon, 2018; Albuquerque et al., 2019; Oliveira et al., 2020).

The teaching, research and extension practices developed by schools, universities and federal institutes are extremely important activities for academic-professional training of students and communities (Silva, 2017). This tripod is a fundamental axis in the activities developed in educational institutions such as the Federal Institutes. The article 207 of the Brazilian Constitution of 1988 highlights the principle of indissociability between teaching, research and extension (Brasil, 1988). The extension has an educational, cultural and scientific character, which enables the transformative relationship between the educational institution and the society (Jantke \& Caro, 2013). 
Over the years, the extension has assumed an important role in the dissemination of knowledge to society, through the University, Technological and Rural Extension. For Portes et al. (2011), the first is the educational, cultural and scientific process that articulates teaching and research in an inseparable way and enables the transforming relationship between the institution and society. The second stands out for the cooperation between the institution and society, aiming to promoting continuous improvement and the increasing of competitiveness of the companies, associations or cooperatives, developing diagnostic actions, technology transfer, technological services, intellectual property and prospecting of technological opportunities to innovation in local economic, social and cultural productive arrangements (IFPA, 2017). The later, in turn, is an extension, on the part of scientific knowledge of a transdisciplinary nature (Gonçalves et al., 2016), respectively.

In this perspective, to speak of extension is to work in a transversal way with other areas of knowledge, as well as the pedagogy, the agronomy, the biology, the history, the geography, the communication, the sociology, the rural anthropology, the popular mobilization, the political science, the rural economy, the agriculture and the aquaculture (Silva, 2017). It is worth mentioning that aquaculture is a science that produces aquatic organisms (Mmanda et al., 2020), which works in confined environments in any of its stages of development (eggs, larvae, postlarvae, juveniles or adults) (Valenti, 2002), being important in extension projects.

The process of technical training of communities is one of the main objectives of extension projects linked to aquaculture and constitutes an important tool in the construction of this dialogue between extensionists and rural producers (Verdejo, 2006; Oliveira, 2015; Marinho \& Freitas, 2015; Caporal \& Dambros, 2017). Therefore, it is important to point out that there is a need to adapt the technical knowledge obtained in the classroom to a simpler language, in order to facilitate the understanding by the fish farmers (Sobral et al., 2020).

Therefore, the use of active methodologies can help in the learning process of these communities, which are targets of extension projects. This type of methodology is used to allow the student/participant to interact with the subject in study (listening, speaking, asking, discussing, doing and teaching), being encouraged to build knowledge (Barbosa \& Moura, 2013, p.55).

Among the various active methodologies that exist and are used widely in the educational process and that can be adapted to training courses for fish farmers, one can mention: learning based in problems and in projects, Peer instruction, team-based learning (TBL), case methods and simulations among others (Rocha \& Lemos, 2014). In this sense, the use of equipment, objects, games and daily situations can be used as tools for the application of active methodologies.

The use of physical models can be used as one of these teaching tools benefiting teachers, students and the community. With the use of pedagogical models, it presents the objective of ensuring the attention, understanding and participation of those involved (Follmann et al., 2016; Fernandes et al., 2019; Almeida et al., 2020). In view of the above, the objective of this work was to evaluate the use of different models for the creation of tambaqui in different environments in the Marajó archipelago, Pará, Brazil.

\section{Methodology}

\subsection{Characterization of the area}

The research (case study) was developed in the municipality of Curralinho, in the Marajó archipelago, state of Pará, Brazil (Figure 1). The Marajó is located on the Amazon coast, that include 16 municipalities which consists the microregions of Arari (Cachoeira do Arari, Chaves, Muaná, Ponta de Pedras, Salvaterra, Santa Cruz do Arari and Soure), Furos de Breves (Afuá, Anajás, Breves, Curralinho and São Sebastião da Boa Vista) and Portel (Bagre, Gurupá, Melgaço and Portel) (Amaral et al., 2012). The Marajó hydrography is composed of drainage networks of recent canals, such as: streams, basins, canals, intricacies, lakes and streams, among which stand out the Rivers Amazonas, Pará, Anapu, Jacundá and Anajás, with their 
numerous tributaries. Curralinho has a territorial extension of 3,620,279 km2 and its population was estimated at 33,893 people for 2018 (IBGE, 2010). Most of this population is fixed in rural communities along the "bores", small rivers that surround the city and near islands, especially the fishermen, extractivists, fish farmers and family farmers.

\subsection{Marajoara fish farming project}

The project "Technology transfer through training and technical assistance for tambaqui breeders (Colossoma macropomum) in the Marajó/PA archipelago", was financed by the Pro-Rectory of Extension and External Relations (PROEX) of the Instituto Federal de Educação, Ciência e Tecnologia do Pará (IFPA), under announcement number 03/2019. For the external public, the project was named "Fish Farming Marajoara", to facilitate the understanding and was conducted by students and teachers of IFPA Campus Breves. The target audience of the project were the fish farmers of the municipality of Curralinho, who are located in the communities: Boa Esperança, Cafezal, Ilha das Araras, Perpétuo Socorro, Piriá Miri, Rio Açú and Santa Izabel, in additon people living in the city's headquarters.

Figure 1 - Location of the municipality of Curralinho, Marajó, Pará, Brasil.

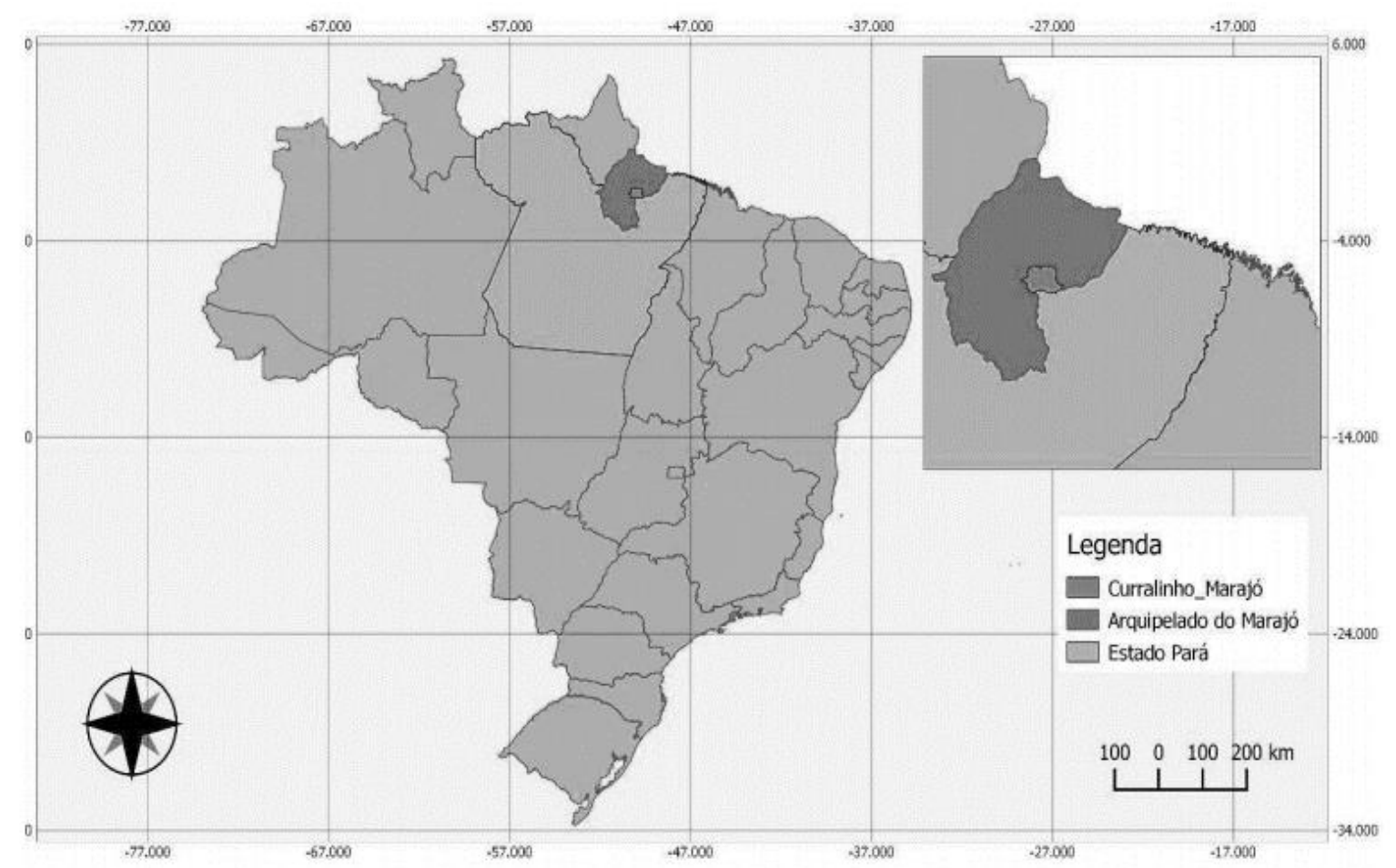

Source: adapted from Aranha \& Lobão (2018).

\subsection{Training course}

The Good Management Practices (BPM's) course in fish farming (theory and practice) was taught by students involved in the project. For this, there were orientations of the students with the teachers of the area of Fishing Engineering and Fishing Resources of IFPA Campus Breves. Initially, a technical meeting was realized with the joint work team to articulation. At this meeting, the extension project was presented and followed a discussion about the BPM course. After that, the target audience was defined and the technical programming was planned to discuss the obstacles in the creation of tambaqui, such as: water quality; indicated species; fish transport management; quarantine and fish settlement; fish biometrics management; liming and fertilizing nurseries; nutrition, feeding and fish health management; fish defishing and slaughter. 
The course was taught in March 2020, lasting 20 hours. During the execution, active methodologies were used through the participation of teachers, cursists and students, such as the construction of model. Simple language was used for constructions in order to provide a better understanding on the part of fish farmers. Alternative and low-cost materials were used for the preparation, taking into account the local reality.

\subsection{Construction of the models}

Three models were produced with a perspective of fish farming implementation in different environments: lowland area, land area and field area (Figure 2). Several materials were used, such as: expanded polystyrene plates (EPS - Stake $\left.{ }^{8}\right)$ of $5 \mathrm{~mm}$, glue for EPS, silicone glue, cardboard, scissors, brush, stiletto, gouache paint, sawdust, plastic lollipop stick, marker, electric cables, spray paints, plastic bags and miniatures.

\subsection{Questionnaire for evaluation of the models used in the project}

At the end of the BPM's course in fish farming were realized dialogues and a qualitative evaluation using the satisfaction scale adapted from Likert (1932). In this scale, the participant can classify in bad, good, very good and great each question of the questionnaire that was built specifically for the models, and all evaluations presented questions about the fixation of the participants' attention, whether the activity helped in understanding the subject, if the fish farmer reflected on the theme approached and whether the time of use of this method was sufficient to add new information.

\subsection{Ethical considerations}

The project was approved by the Research Ethics Committee of the Institute of Health Sciences (CEP) of the Universidade Federal do Pará (UFPA), registration number 2,576,907. The identities of the participants were kept confidential, ensuring their anonymity and confidentiality of the information.

\subsection{Statistical analysis}

The collected data were analyzed through descriptive statistics (Oladejo, 2010). 
Figure 2 - Models for the creation of tambaqui in a floodplain area (A), dry land (B) and field (C), in the Marajó archipelago, Pará, Brazil.

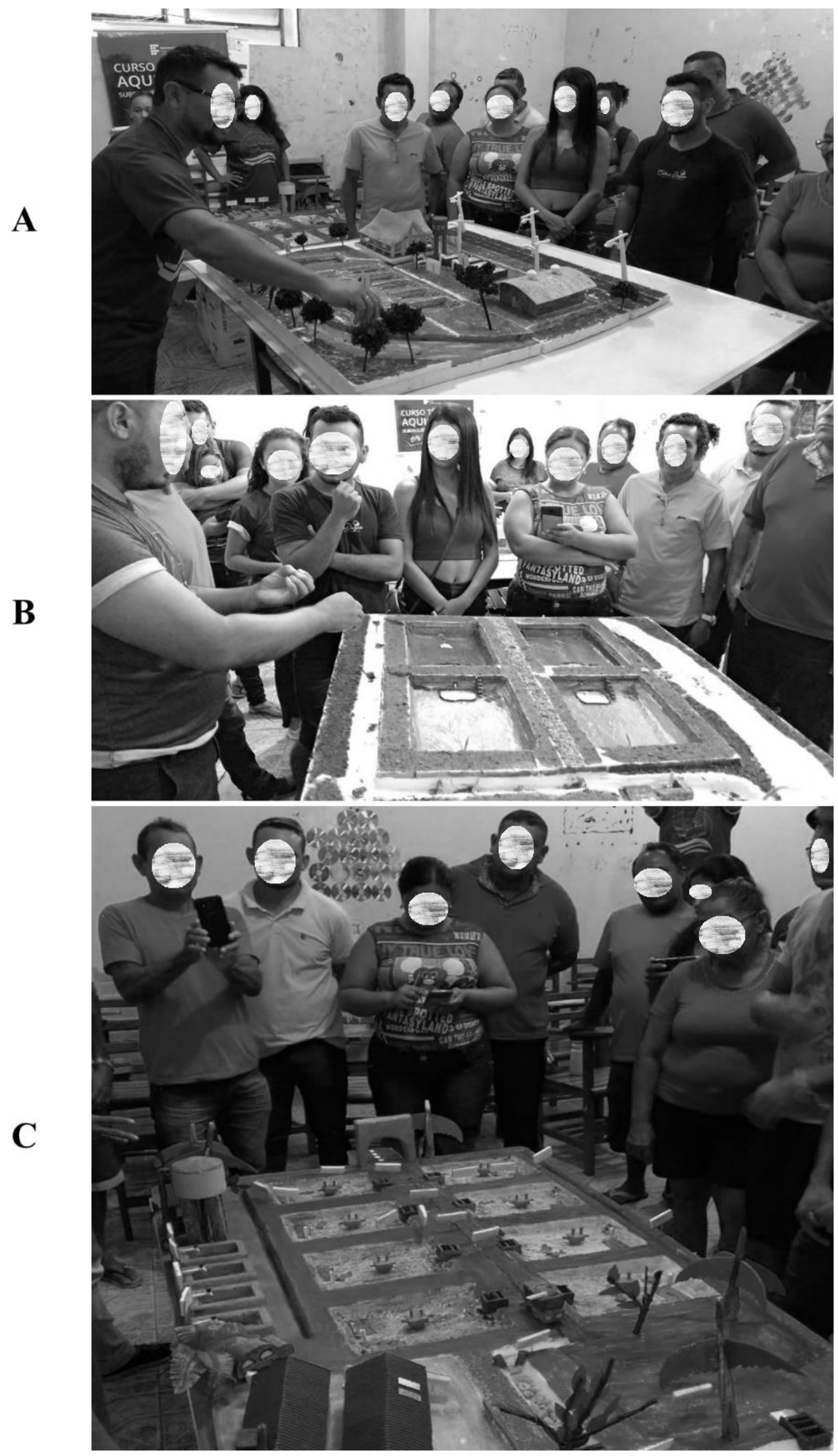

Source: Authors (2020). 


\section{Results and Discussion}

The experience of constructing and using active methodologies through models for the creation of tambaqui ensured the participants greater perception and simulation of the scenarios, where the possibility of three-dimensional visualization made clearer the abstraction and understanding of the different contexts mentioned. The figure 3 shows the results that the measures used in the training in BPM's in fish farming stimulated the interest and fixation of the attention of the producers.

The data indicate that the best results regarding the attention of fish farmers were achieved with the model lowland area (Figure 2-A), having the highest evaluation scores. Then, the environments of dry land and field presented lower scores, demonstrating to capture less attention by the participants. Pitano \& Roqué (2015) observed that the use of models has the ability to generate curiosity and that the artistic process of construction attracts attention and interest, providing greater motivation and involvement with the material in study, which intensifies the teaching-learning process.

Figure 3 - Evalution of different educational models that stimulate the attention of fish farmers by explanations.

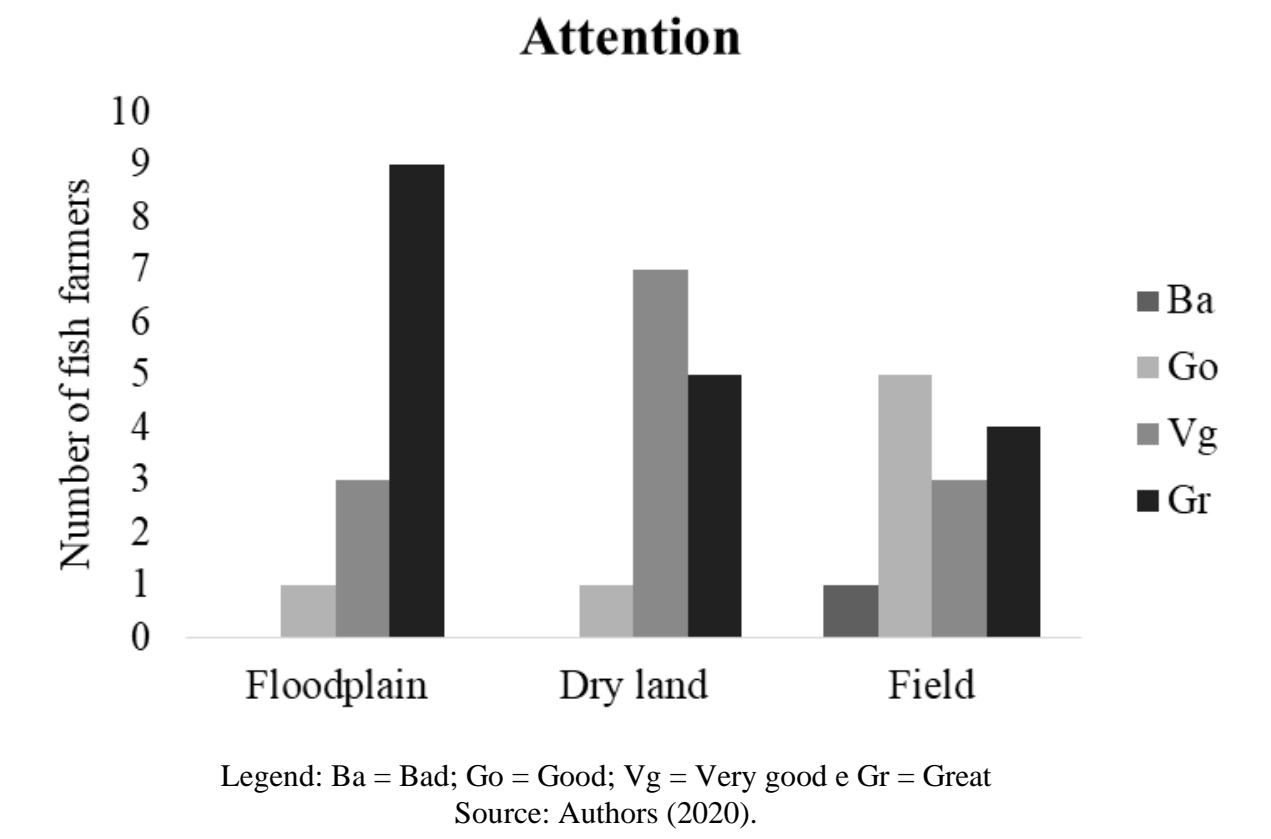

A second parameter evaluated was the understanding of the themes approached using the three educational models, in fish farming in the floodplain, dry land and field area (Figure 4). Once again, the model focusing on the floodplain area (Figure 2-A) presented the best evaluations regarding comprehension, while the other maquetes obtained similar grades, with emphasis on the "very good" evaluation. This result corroborates with Silva \& Muniz (2012) observed, who affirmed that the construction of this didactic resource allows the better understanding of the space is being worked, valuing the previous knowledge of the individuals involved. 
Figure 4 - Evaluation of different educational models that facilitate the comprehension of fish farmers by explanations.

\section{Comprehension}

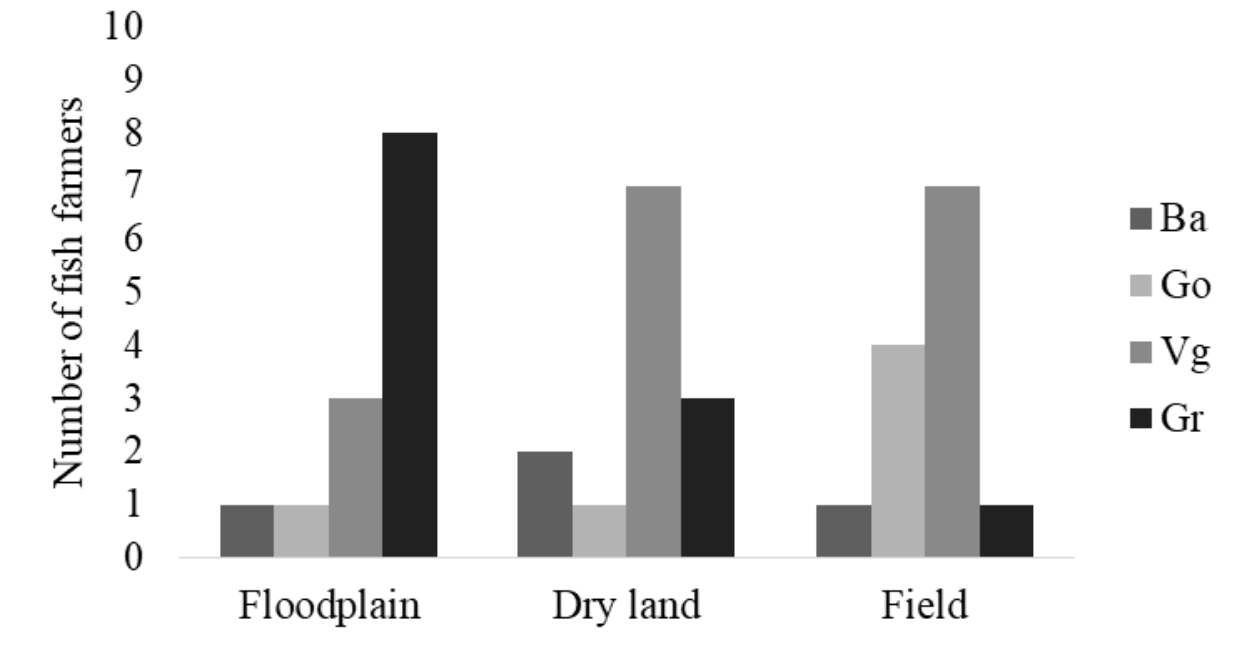

Legend: $\mathrm{Ba}=\mathrm{Bad} ; \mathrm{Go}=\mathrm{Good} ; \mathrm{Vg}=$ Very good e $\mathrm{Gr}=$ Great Source: Authors (2020).

A third parameter to be analyzed through Likert scale was how much the teaching methodology used, whether it stimulated personal reflection on the subject and how much it persuaded the fish farmers in relation to the subjects exposed (Figure 5). The fish farming model in a floodplain area (Figure 2-A) presented the highest rate of the classification "Great" with $79 \%$, where a possible justification is that fish farming in this area stimulates the participant to think, focus on a small time interval and focus on what is being required in the activity. This result increased what was verified by Fernandes et al. (2018), which highlighted that the use of models can promote a space of interaction, and cause new reflections and representations about the subjects' daily lives. An interesting index was achieved with the dry land model, with $69 \%$ of the fish farmers classifying it as "Great"; this demonstrated that this activity had a significant reflexive and persuasion power. 
Figure 5 - Evaluation of different educational models that stimulate the reflection of fish farmers by explanations.

\section{Reflection}

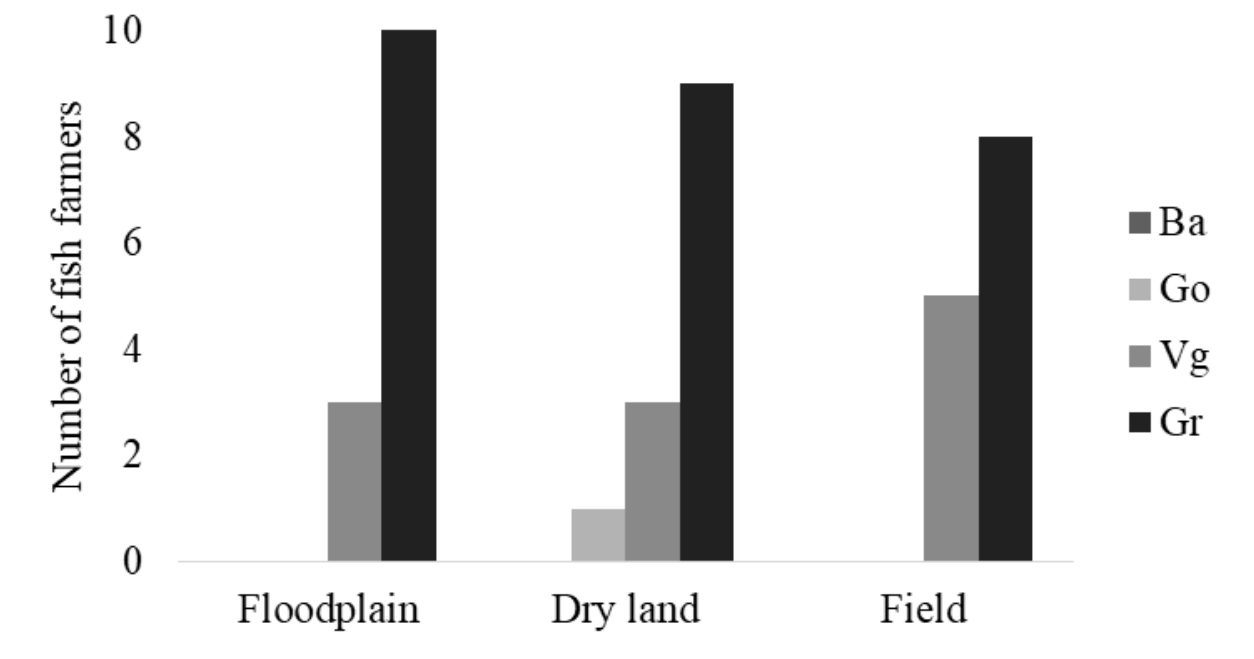

Legend: $\mathrm{Ba}=\mathrm{Bad} ; \mathrm{Go}=$ Good; $\mathrm{Vg}=$ Very good e $\mathrm{Gr}=$ Great Source: Authors (2020).

Again, the use of models demonstrating fish farming in the field area (Figure 2-C) as playful tools did not present the best opinions of the fish farmers participating in the extension project. Only $62 \%$ of them affirmed that the use of this model stimulated the reflection under the theme approached, classifying the tool as "Great", and 38\% classified this form as "very good".

Finally, the Figure 6 shows the results of the evaluation by fish farmers concern to the time of each activity, if the time would have been sufficient for the acquisition of new information about fish farming as a possible way to evaluate efficiency. The fish farmers classified the time of exposure of the floodplain area model (Figure 2-A) as "great" (77\%), "very good" (15\%) and "good" (8\%), while for the dry land (Figure 2-B) the rates were 62\% for "great", 23\% "very good" and 15\% for "good". Finally, the opinions regarding to the time used with the model in the field area (Figure 2-C) were more diverse: 54\%, 31\%, 8\% and 7\% for "Great", "Very good", "Good" and "Bad", respectively. 
Figure 6 - Evaluation of the sufficiency of the time used with different educational methodologies for the construction of new knowledge on topics approached in pedagogical workshops.

\section{Time}

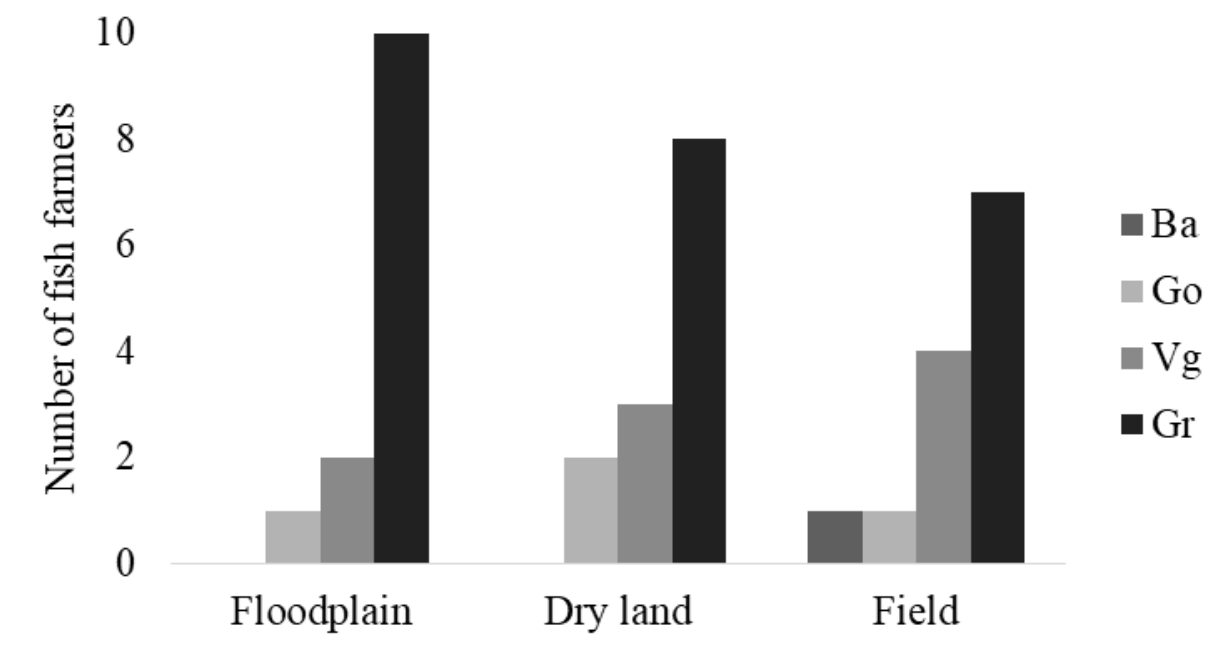

Legend: $\mathrm{Ba}=\mathrm{Bad} ; \mathrm{Go}=\mathrm{Good} ; \mathrm{Vg}=$ Very good e $\mathrm{Gr}=$ Great Source: Authors (2020).

\section{Final Considerations}

Informations about the creation of tambaqui for local producers using active methodologies through models, as pedagogical instruments for simulations of technical demonstrations and sharing of experiences among those involved. The evaluations of the fish farmers participants showed higher levels of active learning with the model related to fish farming of tambaqui in a floodplain area. The use of such tools brought very positive results in the learning process during the educational actions of the extension project.

\section{Acknowledgements}

To the Pro-Rectory of Extension (PROEX) of the Instituto Federal de Educação, Ciência e Tecnologia do Pará (IFPA), for funding in the research (Notice No. 03/2019).

\section{References}

Albuquerque, D. M., Herrig, E. A., \& Cavichiolo, F. (2019). Aquicultura como ferramenta de interação entre Universidade e Sociedade. Revista online de extensão e cultura, 6 (12), 36-43.

Alcântara, P. H. R., Sousa, D. N., Mataveli, M., Evangelista, D. K. R., \& Pinho, M. S. (2017). Piscicultura de água doce: análise da capacitação de multiplicadores. Brasília: EMBRAPA.

Almeida, M. S., Castro, J. N., Cruz, W. T., \& Almeida, R. Q. (2020). Construção de uma maquete do sistema solar com controle de temperatura para alunos com deficiência visual. Revista Brasileira de Ensino de Física, 42, 20190098.

Amaral, D. D., Mantelli, L. R., \& Rossetti, D. F.(2012). Paleoenvironmental control on modern forest composition of southwestern Marajo Island, Eastern Amazonia. Water and Environment Journal, 26, 70-84.

Aranha, T. V., \& Lobão, R. A. (2018). Do extrativismo a produção: experiência de piscicultura em comunidades ribeirinhas de Curralinho - Marajó (PA). Nova Revista Amazônica, 1 . 
Brasil (2003). Constituição (1988). Constituição da República Federativa do Brasil. (31a ed.) São Paulo: Saraiva.

Barbosa, E. F., \& Moura, D. G. (2013). Metodologias ativas de aprendizagem na Educação Profissional e Tecnológica. B. Tec. Senac, Rio de Janeiro, 39 (2), 48-67.

Cantisani, D. M., Floriano, L. S., Ribeiro, G. K. F., Barcelos, T. C., Cunha, J. M. S., Souto, C. N., \& Souza, R. A. (2015). Produção de peixe como estratégia de fixação do homem do campo. Fragmentos de cultura, 25 (1), 123-133.

Caporal, F. R., \& Dambros, O. (2017). Extensão Rural Agroecológica: experiências e limites. Redes, 22, $275-297$.

Fernandes, T. G., Araujo, B. G. O., Sousa, D. M., Gomes, T. Q., \& Cruz, M. L. B. (2019). A construção de maquetes como recurso didático no ensino de geografia. Revista Equador (UFPI), 7 (2), 96-109.

Follmann, F. M., Losekann, M. B., \& Degrandi, S. M. (2016). A construção e utilização de maquetes no ensino de geografia do Brasil. Revista de Extensão, 3.

Gonçalves, L. C., Ramirez, M. A., \& Santos, D. (2016). Extensão rural e conexões. Belo Horizonte: FEPMVZ, 164.

IBGE. (2010). Instituto Brasileiro de Geografia e Estatística. Censo Demográfico 2010. Resultados gerais da amostra. Rio de Janeiro: IBGE. https://biblioteca.ibge.gov.br/visualizacao/pe riodicos/93/cd_2010_caracteristicas_populacao_domicilios.pdf.

IFPA (2017). Resolução 174/2017- CONSUP de 25 de abril de 2017. Estabelece os fundamentos, os princípios e as diretrizes para as atividades de extensão do Instituto Federal de Educação, Ciência e Tecnologia do Pará. Instituto Federal de Educação, Ciência e Tecnologia do Pará.

Ituassú, D. R., \& Aragão, J. C. (2018). Sistema treino e visita de piscicultura em Mato Grosso, Brasil. Cadernos de Ciência \& Tecnologia, 35(2), 163-172.

Jantke, R. V. R., \& Caro, S. M. P. (2013). A extensão e o exercício da cidadania. In: Luiz Síveres. (Org.). A extensão universitária como princípio de aprendizagem. 1ed.Brasília: Liber Livro, 1, 97-108.

Likert, R (1932). A technique for the measurement of attitudes. Archives of psychology, 140, 1-50.

Marinho, C. M., \& Freitas, H. R. (2015). Utilização de metodologias participativas nos processos de assistência técnica e extensão rural (ATER): fundamentos teórico-práticos. Revista de Extensão da UNIVASF, 3 (2).

Mmanda, F. P., Mulokozi, D. P., Lindberg, J. E., Norman Haldén, A., Mtolera, M., Kitula, R., \& Lundh, T. (2020). Fish farming in Tanzania: the availability and nutritive value of local feed ingredients. Journal of Applied Aquaculture, 1 (20).

Oliveira, E. C., Santos, D. C., Pereira, E. C., Silva, J. C., \& Silva, L. V. F. (2020). Treinamento em reprodução de peixes: uma troca de experiências com piscicultores. Brazilian Journal of Development, 6 (3), 11597-11607.

Oliveira, M. L. R. (2015). Reflexões sobre o uso de metodologias participativas como instrumento de trabalho em comunidades rurais. Em Extensão, 14 (1), $30-51$.

Pitano, S. C., \& Roqué, B. B. (2015). O uso de maquetes no processo de ensino-aprendizagem segundo licenciandos em Geografia. Educação Unisinos. 19 (2), 273-282.

Portes, M. R., Ananias, S. P., \& Teixeira, H. A. (2011). Ensino do Empreendedorismo e Extensão Universitária: uma política pedagógica articulada. Anais... In: VIII - Congresso Virtual Brasileiro de Administração, Brasília. 
Research, Society and Development, v. 10, n. 1, e011011087, 2021 (CC BY 4.0) | ISSN 2525-3409 | DOI: http://dx.doi.org/10.33448/rsd-v10i1.10187

Silva, F. N. L. (2017). "Piscicultura marajoara”: formação extensionista, diagnóstico e intervenções em comunidades por educandos do Instituto Federal de Educação, Ciência e Tecnologia do Pará campus Breves. Especialização em Docência para o Ensino Tecnológico, Científico e Profissional, 131 f. Instituto Federal de Educação, Ciência e Tecnologia do Pará-IFPA, Campus Breves.

Silva, V., \& Muniz, A. M. V. (2012). A geografia escolar e os recursos didáticos: o uso das maquetes no ensino-aprendizagem da geografia. Geosaberes, Fortaleza, 3 (5), 62-68.

Sousa, R. G. C., Assis, J. L., Cozer, M. V. G., \& Oliveira, C. M. (2019). Socio-Economic profile of fish farming in Presidente Médici (Rondônia - Brazil). Biota Amazônia, 9 (1), 51-55, 2019.

Sobral, V. R., Pontes, M. F., \& Carvalho, I. R. (2020). O projeto de ensino como ferramenta de integração entre comunidade e o instituto federal de Roraima, Campus Amajari. Brazilian Journal of Development, 6 (2), 8948-8959.

Valenti, W. C. (2002). Aquicultura sustentável. In: Congresso De Zootecnia, 2002, Vila Real, Portugal. Anais... Vila Real: Associação Portuguesa dos Engenheiros Zootécnicos, 111-118.

Verdejo, M. E. (2006). Diagnóstico Rural Participativo: Guia Prático DRP. Brasília: MDA/ Secretaria de Agricultura Familiar, 62.

Rocha, H. M., \& Lemos, W. M. (2014). Metodologias ativas: do que estamos falando? Base conceitual e relato de pesquisa em andamento. Anais [...] IX Simpósio Pedagógico e Pesquisas em Educação, 1-12. 